\title{
Pressure Induced Bonding Changes in Carbon Dioxide: Six Fold Coordinated $\mathrm{CO}_{2}$
}

Valentin lota, Zsolt Jenei, Jae-Hyun P. Klepeis, William J. Evans and Choong-Shik Yoo

LDRD Final Report 07-LW-049

February 11, 2008 


\section{Disclaimer}

This document was prepared as an account of work sponsored by an agency of the United States government. Neither the United States government nor Lawrence Livermore National Security, LLC, nor any of their employees makes any warranty, expressed or implied, or assumes any legal liability or responsibility for the accuracy, completeness, or usefulness of any information, apparatus, product, or process disclosed, or represents that its use would not infringe privately owned rights. Reference herein to any specific commercial product, process, or service by trade name, trademark, manufacturer, or otherwise does not necessarily constitute or imply its endorsement, recommendation, or favoring by the United States government or Lawrence Livermore National Security, LLC. The views and opinions of authors expressed herein do not necessarily state or reflect those of the United States government or Lawrence Livermore National Security, LLC, and shall not be used for advertising or product endorsement purposes.

\section{Auspices Statement}

This work performed under the auspices of the U.S. Department of Energy by Lawrence Livermore National Laboratory under Contract DE-AC52-07NA27344. This work was funded by the Laboratory Directed Research and Development Program at LLNL under project tracking code 07-LW-049 


\title{
FY07 LDRD Final Report Pressure Induced Bonding Changes in Carbon Dioxide: Six Fold Coordinated $\mathrm{CO}_{2}$
}

\author{
LDRD 07-LW-049 \\ Valentin Iota, Principal Investigator
}

\begin{abstract}
In this LDRD, we examined in detail the pressure-induced bonding and local coordination changes leading to the molecular $\rightarrow$ associated $\rightarrow$ extended-solid transitions in carbon dioxide $\left(\mathrm{CO}_{2}\right)$. We studied the progressive delocalization of electrons from the $\mathrm{C}=\mathrm{O}$ molecular double bond at high pressures and temperatures, and determined the phase stability and physical properties of a new extended-solid $\mathrm{CO}_{2}$ phase (VI). We find that the new $\mathrm{CO}_{2}$ phase $\mathrm{VI}$ is based on a network of six-fold coordinated (octahedral) $\mathrm{CO}_{6}$ structures (similar to the ultra-hard $\mathrm{SiO}_{2}$ phase stishovite.
\end{abstract}

\section{Introduction/Background}

At pressures below $10 \mathrm{GPa}, \mathrm{CO}_{2}$ is a prototypical simple molecular solid, stabilized by strong $\pi$ bonding within the linear-symmetric molecules, and relatively weak quadrupolar intermolecular interactions. At high pressures and temperatures, however, $\mathrm{CO}_{2}$ transforms to a series of solid polymorphs with differing intermolecular interactions, chemical bonding and crystal structure. Important here is the extended covalent solid (polymeric) $\mathrm{CO}_{2}-\mathrm{V}$, formed above $35 \mathrm{GPa}$ and $1800 \mathrm{~K}$. Its structure is based on corner sharing $\mathrm{CO}_{4}$ tetrahedra, similar to that of $\mathrm{SiO}_{2}$ tridymite.

One of the important questions we explored in this study was the existence of additional $\mathrm{CO} 2$ extended-solid polymorphs, in particular, the stability of a 6 -fold coordinated solid - equivalent to $\mathrm{SiO}_{2}$ stishovite.

\section{Research Activities}

We explored the phase diagram of $\mathrm{CO}_{2}$ at pressures up to $100 \mathrm{GPa}$ and temperatures up to $3000 \mathrm{~K}$ by using heated diamond anvil cells (DAC). Experiments up to $1000 \mathrm{~K}$ used external (resistive) heating coils wrapped around the DAC, whereas laser heating techniques were used above $1000 \mathrm{~K}$.

The phase stability and physical properties of $\mathrm{CO}_{2}$ samples were determined in situ by a combination of RAMAN spectroscopy and X-ray diffraction measurements. In addition, we used X-ray Raman Spectroscopy measurements on quenched samples to determine the bonding characteristics of the resulting $\mathrm{CO}_{2}$ phases.

\section{Results/Technical Outcome}

Our study established the stability and physical properties of a new covalent $\mathrm{CO}_{2}$ phase formed by compressing the intermediate phase II at pressures above 50GPa and temperatures above $550 \mathrm{~K}$. Raman and XRD measurements show that the structure of $\mathrm{CO}_{2}$-VI is based on six-fold coordinated $\mathrm{C}$ (octahedral $\mathrm{C}-\mathrm{O}$ units) similar to the $\mathrm{Si}-\mathrm{O}$ arrangement in stishovite. In addition, we derived a new phase diagram for carbon dioxide, based on the bonding changes in $\mathrm{CO}_{2}$ from molecular to intermediate phases and finally to fully covalent phases at higher pressures. 


\section{Summary}

This LDRD studied in details the phase/structural/bonding phase diagram of $\mathrm{CO}_{2}$ - a prototypical molecular crystal - at high pressure and temperature. Our results are important beyond $\mathrm{CO}_{2}$ - improving our understanding of pressure-induced bonding changes in molecular solids.

\section{Publications:}

1) Six-fold coordinated carbon dioxide VI, V. Iota, CS. Yoo, JH. Klepeis, Z. Jenei, W. Evans and H. Cynn, Nature Materials 6, 34 (2007)

\section{Invited Presentations:}

1) Bonding Changes in Compressed Carbon Dioxide: A New Stishovite-like Phase of $\mathrm{CO}_{2}$ APS March Meeting, March 2007, Denver, Colorado

2) Bonding Changes in Compressed Carbon Dioxide, SMEC conference, Miami Beach, April 2007

3) Bonding and coordination changes in compressed carbon dioxide, Joint 21 st AIRAPT and 45th EHPRG International Conference on High Pressure Science and Technology, Catania, Italy, September 2007

4) A New Six-fold Coordinated Covalent Phase of $\mathrm{CO}_{2}$, APS DOE Technical Review, Argonne Aational Laboratory, 2008 